\title{
Bio-foam from Kraft Black Liquor
}

\author{
Esra CEYLAN ${ }^{*}, 1$, Gülyaz AL ${ }^{2}$, Ayben KILIÇ-PEKGÖZLÜ ${ }^{1}$, Deniz AYDEMİR ${ }^{1}$ \\ ${ }^{1}$ Bartın University, Faculty of Forestry, Department of Forest Industrial Engineering, Bartın, TURKEY. \\ ${ }^{2}$ Çanakkale Onsekiz Mart University, Vocational School of Technical Sciences, Çanakkale, TURKEY
}

\begin{abstract}
Bio-based materials have superior properties in terms of health and environmental friendly as compared with synthetic materials. This makes bio-based materials a good alternative for the future. The sensitivity on this issue has increased even more with the natural disasters that have occurred in recent years and the depletion of resources. In this study, it was aimed to develop alternative bio-based material foams from wastes of paper mills to petroleumbased foams. The mixtures of black liquor and pine bark as the paper mill wastes were selected as the main materials in the production of bio-foams. The changes in the foam structure were determined by adding with different rates of Tween 80 and protein foaming agents ( $2 \mathrm{~g}$ and $4.4 \mathrm{~g}$ ). The structural and chemical properties of the foams were determined using scanning electron microscopy (SEM) and Fourier Transform Infrared spectroscopy (FTIR), respectively. In SEM analysis, the maximum cell size was found as $55.24 \mu \mathrm{m}$ for the F-3 (2 g protein foaming agent) sample, while the minimum cell size was $15 \mu \mathrm{m}$ for F-1 (4.4g protein foaming agent) sample. The maximum and minimum cell size and wall thickness were determined respectively as $5.93 \mu \mathrm{m}$ for F2 (4.4g Tween 80) sample and $3.66 \mu \mathrm{m}$ for F-4 (2 g Tween 80$)$ sample. Bio-foam from kraft liquor has shown a promising success with its foaming features and adequate porous structure for using as an insulation material. By replacing petroleum-based foams with bio-based foams, a new value-added alternative material can be produced from paper mill wastes.
\end{abstract}

Keywords: Paper mill wastes, Bio-foams, material characterization, sustainable forest resources.

\section{Kraft Siyah Likörden Biyo-köpük Eldesi}

\section{Öz}

Biyo esaslı malzemelerin sağlık ve çevreye dost olma açısından sentetiklerden üstün özellikleri vardır ve bu durum biyo malzemeleri geleceğin iyi bir alternatif malzemesi yapmaktadır. Son yıllarda meydana gelen doğal afetler ve kaynakların tükenmesi ile karşı karşıya kalınması ile bu konudaki hassasiyet daha da artmıştır. Bu çalışmada petrol esaslı köpüklerin yerine geçebilecek biyo-esaslı alternatif bir köpük malzeme geliştirilmesi hedeflenmektedir. Kağıt üretim atığı olan siyah likör ve karışık çam kabukları biyo-köpük eldesinde ana materyaller olarak tercih edilmiştir. Tween 80 ve protein köpük ajanı farklı oranlarda (2 ve 4,4 g) kullanılmış ve biyo-köpük yapısına etkileri karşılaştırılmıştır. Köpüklerin yapısal özellikleri taramalı elektron mikroskopu (SEM), kimyasal özellikleri ise Fourier dönüşümlü kızılötesi spektroskopisi (FTIR) kullanılarak belirlenmiştir. SEM analizleri sonucunda maksimum hücre boyutu F-3 (2 g protein köpük ajanı) örneğinde $55.24 \mu \mathrm{m}$ olarak, minimum hücre boyutu ise F1 (4,4 g protein köpük ajanı) örneğinde $15 \mu \mathrm{m}$ olarak ölçülmüştür. Maksimum ve minimum hücre boyutu ve duvar kalınlıkları sırasıyla 5,93 $\mu \mathrm{m}$ ile F-2 (4,4 Tween 80) örneğinde, $3.66 \mu \mathrm{m}$ ile F-4 (2 g Tween 80) örneğinde tespit edilmiştir. Kraft siyah liköründen üretilen biyo-köpük, yalıtım malzemesi olarak kullanılmaya yeterli köpüklenme özelliği ve poroz yapısı ile umut verici bir başarı göstermiştir. Petrol esaslı köpüklerin yerini biyo-esaslı köpüklerin alması ile katma değeri yüksek alternatif materyaller, kağıt fabrikası atıklarından üretilebilir.

Anahtar Kelimeler: Kağıt fabrikası atıkları, biyo-köpükler, materyal karakterizasyonu, sürdürülebilir orman kaynakları. 


\section{Introduction}

The trends towards the conversion of waste/biomass into valuable materials are getting stronger day by day due to the depletion of natural resources, increasing greenhouse emissions, and awareness of the need for sustainable development (Forgacz et al. 2013). Black liquor is a complex and strongly alkaline aqueous mixture, contains dissolved fragments of degraded lignin and hemicelluloses from wood material during the Kraft process. It contains organic biomass materials as lignin, non-cellulosic polysaccharides called hemicelluloses, and low molar mass resinous compounds, and inorganic compounds as mainly soluble ion salts (Forgacz et al., 2013; Foulet et al. 2016).

Black liquor is one of the main by-products of the pulp industry, which contains between 10 and 50 wt\% lignin. The pulp and paper industry discards lignin to produce a quality paper. Lignin, an undesirable compound in pulping process, is highly resistant to microbial attack. It is a mixture of non-biodegradable polyphenolic compounds with a highly complex chemical structure. Therefore, a large part of it merges into water streams or landmass through conventional treatment processes and thus causes severe environmental pollution. (Ksibi et al. 2003; Zaied and Bellakhal, 2009). Barks surround the outer part of woody stems and branches (Diamantopoulou, 2005; Harkin and Rowe, 1971). The bark is a heterogeneous and highly complex material, whose main function is to protect the cambium and prevent loss of water (Harkin and Rowe, 1971). Recycling the surplus bark is one of the biggest problems of wood conversion industries. Nowadays, interest in the use of tree bark is increasing. However, it is still challenging to use bark due to its heterogeneous structure, chemical composition, low strength, and dark color. Bark utilization can contribute to recycling and the economy by creating a new industry (Diamantopoulou 2005; Feng et al. 2013). Due to hierarchical porosity offering several advantages, the design of materials with this property is a highly attractive field of research. Micro-pores and mesopores support solidliquid interactions by creating a large exchange surface area in the material, while macropores allow efficient mass transfer to smaller pores thanks to an effective convection flow (Foulet et al. 2016).

Plastic foams made from different plastic materials such as polystyrene, polyurethane, or polyvinyl chloride have been widely used in various applications such as thermal insulation, weight reduction, packaging, or open-cell cellular ceramic material fabrication. A little part of petroleum-derived foams can be recycled. But since petroleum is not a renewable resource, its intensive use causes various damages to the environment. For these reasons, studies have been carried out since the 1990s to develop bio-sourced foam. (Mathias et al. 2011). According to the studies, it is concluded that foam can be obtained by using black liquor (Forgacz et al. 2013; Foulet et al. 2015; Merle et al. 2019). Polymer foams, also known as porous polymer materials, are widely used materials. With the ongoing developments, polymer foams have been used in many areas of our lives. They are mostly used for packaging as a shock absorber and for thermal insulation and sound absorption on the construction sites (Merle et al., 2019). Polymer foams, one of the most important industrial foams, will have an even wider usage area in the future. Compared to bulk foam materials, polymer foams have many advantages. Polymer foams have low density, good thermal insulation, good sound insulation effects, high specific strength, corrosion resistance, and they are used in many industrial applications (Jin et al. 2019).

This study aims at contributing to the environment and economy by utilizing the unused forest industry wastes as bio-foam. In this study, the chemical structures (FTIR) and morphological characteristics (SEM) of the foams were investigated.

\section{Materials and Methods}

\subsection{Materials}

Kraft black liquor and bark (mixed pine) were obtained from OYKA Pulp Mill as industrial waste. Mixed pine resin was purchased from a local market. Protein foaming agent was obtained from ARTRA Construction. Tween 80 and hexamethylenetetramine were purchased from Merck Millipore.

\subsection{Methods}

\subsubsection{Foam preparation}

The foam preparation was conducted according to the Merle et al. (2019). First, foam materials including the mixture of bark/black liquor, distilled water, resin, protein foaming agent, and hexamine (curing agent) were added to a beaker and then stirred with a laboratory overhead stirrer at $250 \mathrm{rpm}$ for $5 \mathrm{~min}$. then $500 \mathrm{rpm}$ for 5 min. at $60{ }^{\circ} \mathrm{C}$ until the mixture is homogenous. Tween 80 (surfactant) was added as dropwise by stirring at 1800 
rpm for 30 min. to allow air bubbles in the mixture. The mixture was poured into molds for drying in an oven at $85^{\circ} \mathrm{C}$ for $24 \mathrm{~h}$. Four different formulations were prepared (Table 1).

Table 1. Formulations of foams.

\begin{tabular}{lcccc}
\hline & \multicolumn{4}{c}{ Formulations } \\
\hline & F-1 & F-2 & F-3 & F-4 \\
\hline Bark & $23.7 \mathrm{~g}$ & $23.7 \mathrm{~g}$ & $23.7 \mathrm{~g}$ & $23.7 \mathrm{~g}$ \\
Black liquor & $11 \mathrm{ml}$ & $11 \mathrm{ml}$ & $11 \mathrm{ml}$ & $11 \mathrm{ml}$ \\
Distilled water & $83 \mathrm{ml}$ & $83 \mathrm{ml}$ & $53 \mathrm{ml}$ & $53 \mathrm{ml}$ \\
Resin & $3.4 \mathrm{~g}$ & $3.4 \mathrm{~g}$ & $3.4 \mathrm{~g}$ & $3.4 \mathrm{~g}$ \\
Hexamine & $4.5 \mathrm{~g}$ & $4.5 \mathrm{~g}$ & $4.5 \mathrm{~g}$ & $4.5 \mathrm{~g}$ \\
Tween 80 & - & $4.4 \mathrm{~g}$ & - & $2 \mathrm{~g}$ \\
Protein foaming agent & $4.4 \mathrm{~g}$ & - & $2 \mathrm{~g}$ & - \\
\hline
\end{tabular}

\subsubsection{Morphological Characterization}

The morphology of samples was observed with an environmental scanning electron microscopy (SEM) (Tescan MAIA3 XMU-SEM) at an acceleration voltage of $5 \mathrm{kV}$. The surfaces of all samples were sputter-coated with gold using a Denton sputter coater for enhanced conductivity.

\subsubsection{Fourier transform infrared spectroscopy (FTIR)}

Structural changes in bio foams were analyzed by using Shimadzu IRAffinity-1 with a resolution of $4 \mathrm{~cm}^{-1}$. The wavenumber is between $800 \mathrm{~cm}^{-1}$ to $4000 \mathrm{~cm}^{-1}$ with 32 scan.

\section{Results and Discussion 3.1 Electron microscopy investigations (SEM)}

The morphology of the foams was analyzed by SEM. Each foam composition will be discussed severally. In F-1 sample, although there are foaming areas, too many cell collapses have occurred (Figure 1). Generally, the structure has a stratified appearance due to cell collapses and desired foaming did not occur. High amount of protein foaming agent could be the reason of insufficient foaming. Kuranska et al. (2020) stated that the apparent density and the content of closed cell are low in bio-foams modified with bio-polyols. In another study, Zhang et al. (2018) have found out an attractive strategy through a simple lignin surface functionalization with polyisocyanate to develop constructional and structural applications of high-lignin-content rigid polyurethane (RPU) foams. The conversion of lignin hydroxyl groups into lignin urethanes moiety caused the change of lignin surface functionalization, which, therefore, helped disperse and reactivate the good lignin. This would also strengthen the RPU foam mechanical properties.
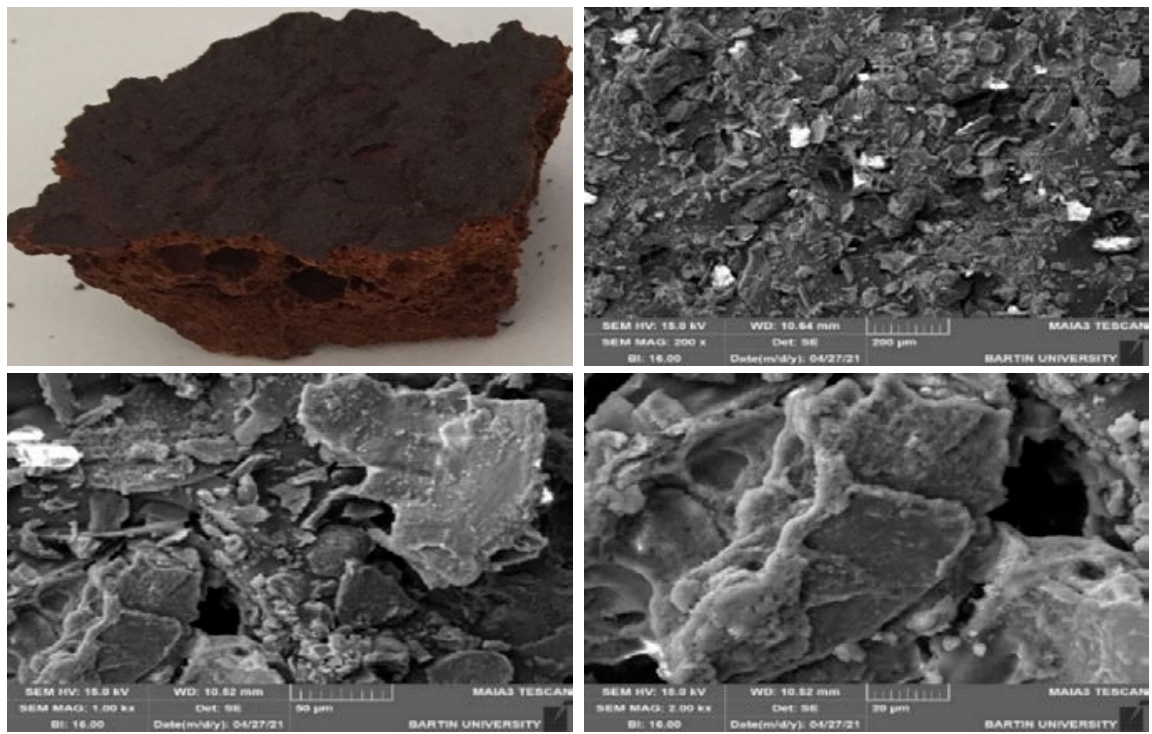

Figure 1: SEM micrographs of F-1 foaming composites. 
In comparison with the F-1 sample, there are less cell collapses and a small amount of foaming in F-2 sample (Figure 2). Generally, there are open cells. Tween 80 was used in F-2 sample as a foaming agent and similar results were obtained like protein foaming agent. High amount of Tween 80 did not show adequate performance.
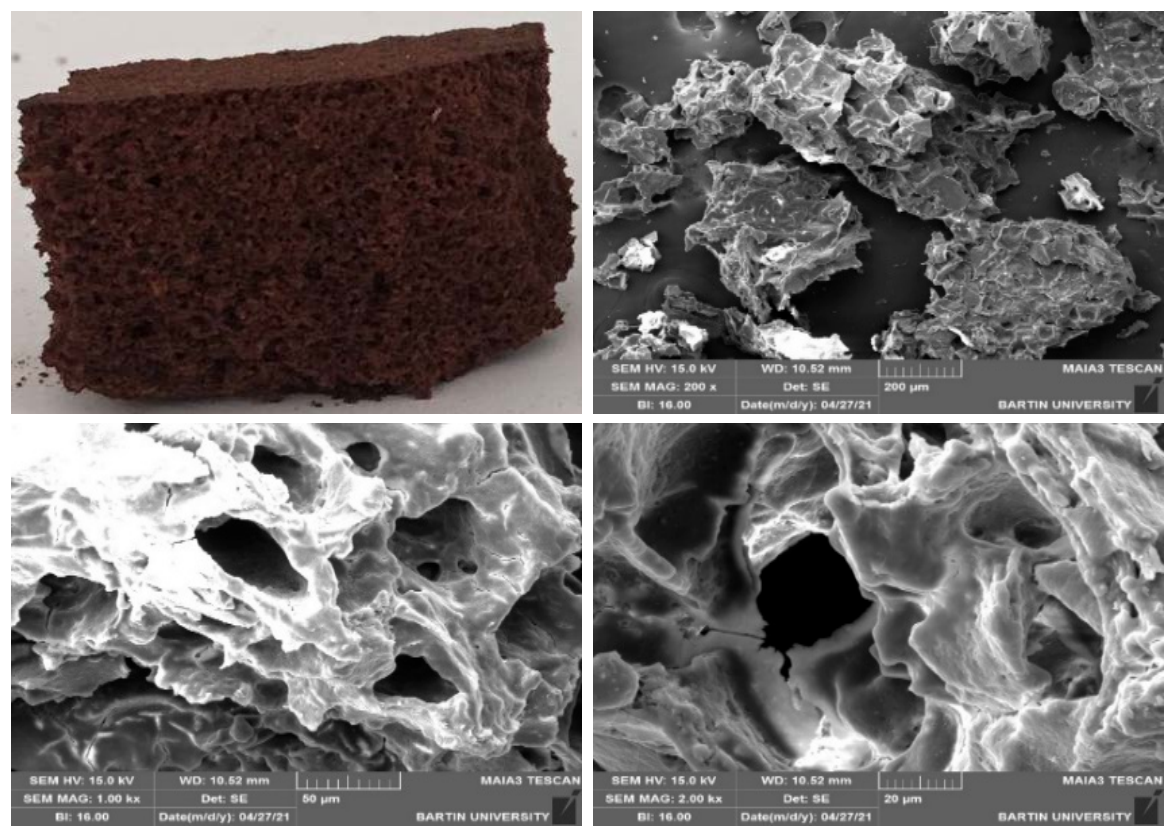

Figure 2: SEM micrographs of F-2 foaming composites.

Decreasing the amount of protein foaming agent to 2 g positively affect the foaming (Fig. 3). In F-3 sample, the cell walls are thick and the nucleation is generally homogeneous (Table 2). Generally, there are open cells.
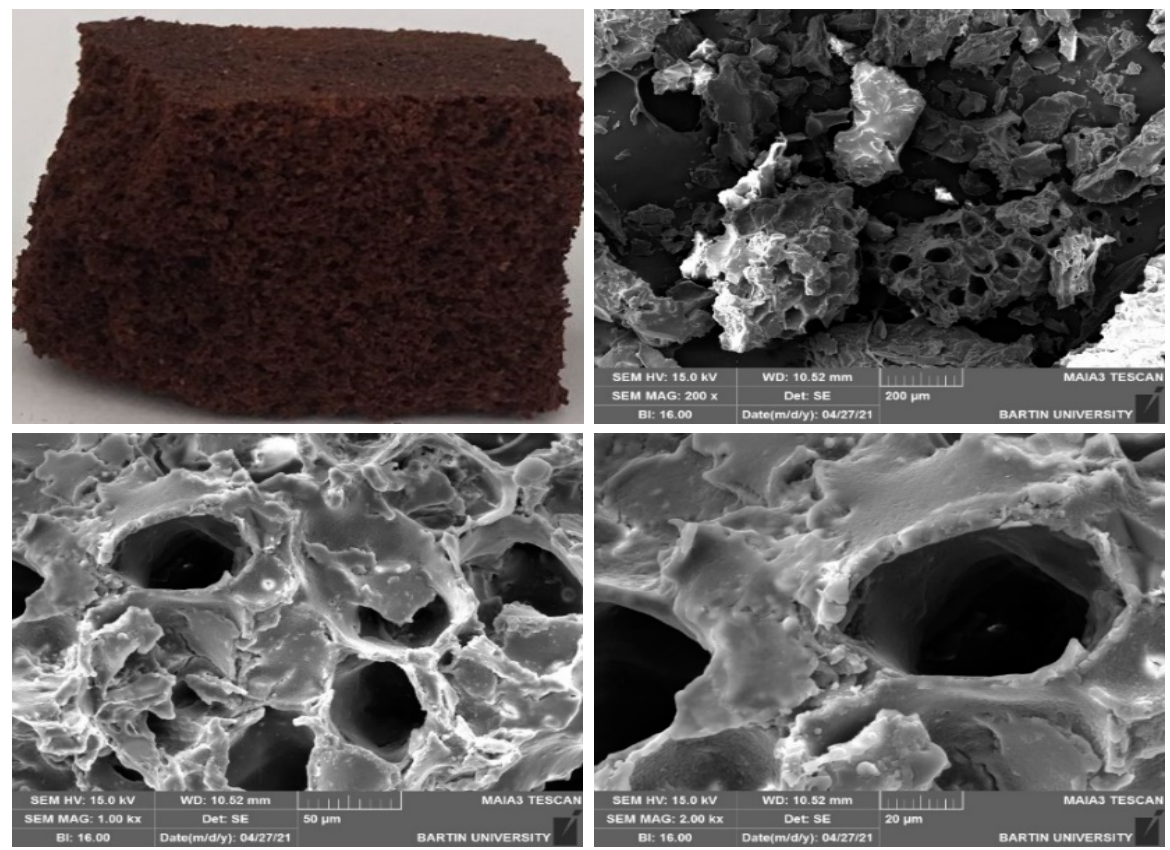

Figure 3: SEM micrographs of F-3 foaming composites.

Similar results were obtained in F-4 sample. Decreasing the amount of Tween 80 give better foaming performance (Fig.4). In addition, when the cells are examined, it was seen that the cells are generally closed cells, the cell walls are thin and the nucleation is generally in a homogeneous structure (Table 2). 

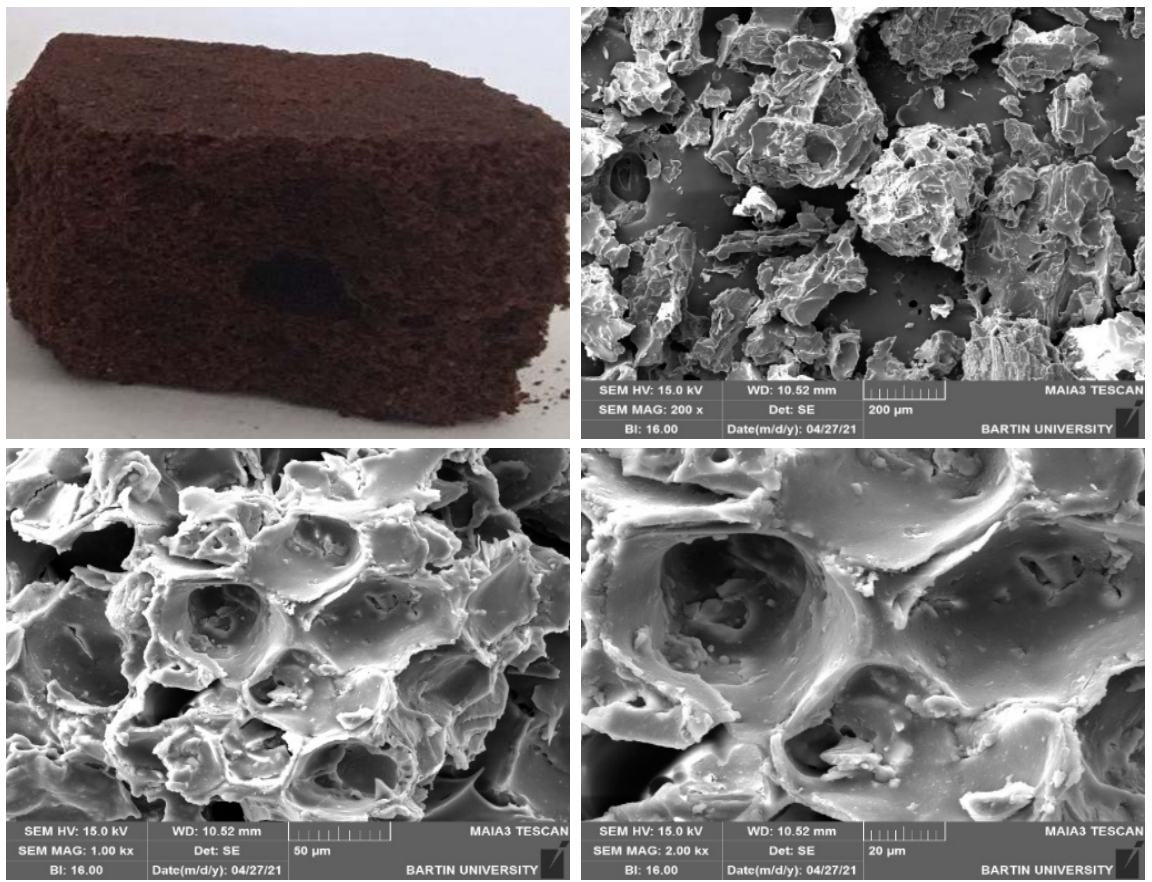

Figure 4: SEM micrographs of F-4 foaming composites.

Table 2. Morphological characteristics of the foams.

\begin{tabular}{lcccc}
\hline \multicolumn{5}{c}{ Morphological characteristics of the foams } \\
\hline & F-1 & F-2 & F-3 & F-4 \\
\hline Average cell diameter $(\boldsymbol{\mu m})$ & 15 & 34.17 & 55.24 & 49.63 \\
Average cell wall thickness $(\boldsymbol{\mu m})$ & - & 5.93 & 5.29 & 3.66 \\
\hline
\end{tabular}

Table 2 shows the average cell diameter and wall thickness of the foamed samples. According to Table 2, the maximum cell size was found as $55.24 \mu \mathrm{m}$ for F-3 samples and the minimum cell size was $15 \mu \mathrm{m}$ for F-1. The maximum and minimum cell size and wall thickness were determined $5.93 \mu \mathrm{m}$ for F-2 and $3.66 \mu \mathrm{m}$ for F-4 samples. In previous studies, SEM images showed that the cell size is significantly affected by bio-polyols including the lignin and pulp fiber contents, which resulted in inhomogeneous, irregular, and large cell shapes and further decreased the densities of the foamed samples (Xue et al. 2014, Luo et al. 2020). As a result, the foaming process of black liquor generally was completed successfully and the porous structure of the obtained foamed samples generally enough to using in manufacturing of the insulation panels.

\subsection{Fourier transform infrared spectroscopy (FTIR)}

FTIR spectra of Tween 80 show peaks nearly at $1614 \mathrm{~cm}^{-1}, 1734 \mathrm{~cm}^{-1}, 2879 \mathrm{~cm}^{-1}$, and $2928 \mathrm{~cm}^{-1}$. The peak at around $1614 \mathrm{~cm}^{-1}$ can be attributed to $\mathrm{O}-\mathrm{H}$ stretching vibrations. The peak at about $1734 \mathrm{~cm}^{-1}$ is the $\mathrm{C}=\mathrm{O}$ stretching of the ester group. The peaks at $2879 \mathrm{~cm}^{-1}$ and $2928 \mathrm{~cm}^{-1}$ are associated with asymmetric (vas) and symmetric (vs) stretching vibrations of methylene (- $\left.\mathrm{CH}_{2}\right)$ (Pramod et al. 2015; Ren et al. 2012). 


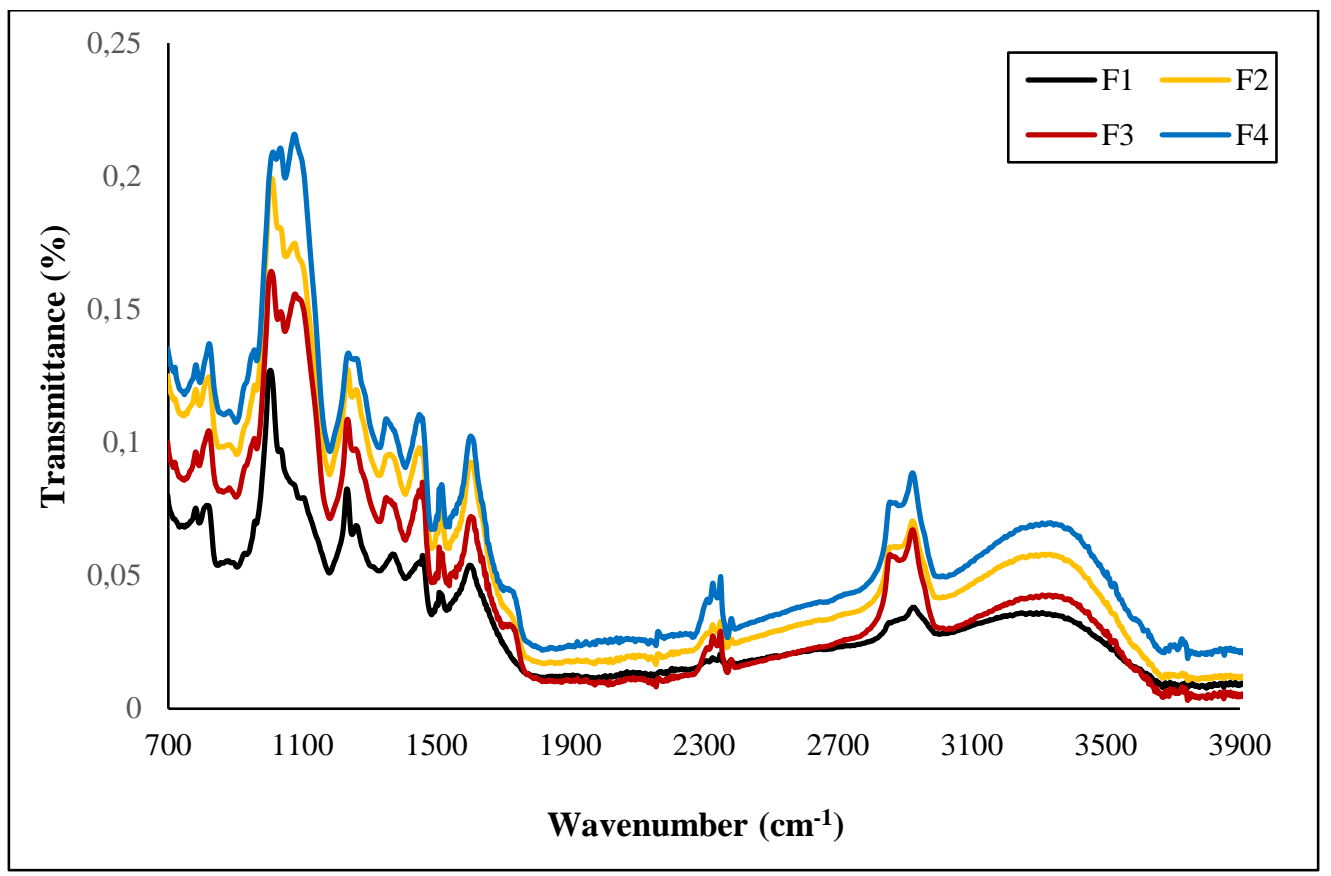

Figure 5: FTIR spectra of foams.

FTIR spectra of black liquor show peaks at $1031 \mathrm{~cm}^{-1}, 1089 \mathrm{~cm}^{-1}, 1462 \mathrm{~cm}^{-1}$ and $1519 \mathrm{~cm}^{-1}$. The peaks at $1031 \mathrm{~cm}^{-}$ ${ }^{1}$ and $1089 \mathrm{~cm}^{-1} \mathrm{C}-\mathrm{O}(\mathrm{H})$ and $\mathrm{C}-\mathrm{O}(\mathrm{C})$ (first order aliphatic $\mathrm{OH}$ and ether), $1462 \mathrm{~cm}^{-1} \mathrm{C}-\mathrm{H}$ deformation (asymmetric in -CH3 and -CH2), and 1519 C-C stretching vibrations (aromatic ring) are seen (Risanto et al., 2014). FTIR spectra of Calabrian pine bark show peaks at $1026 \mathrm{~cm}^{-1}$ and $1264 \mathrm{~cm}^{-1}$. The peak at $1026 \mathrm{~cm}^{-1}$ " C-O stretch is attributed to cellulose and hemicellulose, $1264 \mathrm{~cm}^{-1} \mathrm{G}$-ring plus $\mathrm{C}=\mathrm{O}$ stretch attributed to G-Lignin (Özgenç, et al., 2017).

Bands between $810 \mathrm{~cm}^{-1}-820 \mathrm{~cm}^{-1}$ indicate the presence of hexamine (García et al. 2010).

\section{Conclusions}

As a result of the analysis, it was found that;

- A better porous structure occurs when foaming agents have been used at low rates (appx. 2 g).

- Also, cell diameters have increased when foaming agents have been used at low rates.

- It has been seen that compared to the protein foaming agent, Tween 80 is more successful in the porous material.

- Kraft pulping wastes can be utilized as main components of bio-foam production.

\section{Acknowledgment}

We would like to thank to OYKA Pulp Mill for their contribution to the supply of this research.

\section{References}

1. Diamantopoulou, M. J. (2005). Artificial neural networks as an alternative tool in pine bark volume estimation. Computers and Electronics in Agriculture, 48(3), 235-244. https://doi.org/10.1016/j.compag.2005.04.002

2. Feng, S., Cheng, S., Yuan, Z., Leitch, M., Xu, C. (2013). Valorization of bark for chemicals and materials: A review. Renewable and Sustainable Energy Reviews, 26, 560-578. https://doi.org/10.1016/j.rser.2013.06.024

3. Forgacz, C., Birot, M., Deleuze, H. (2013). Synthesis of porous emulsion-templated monoliths from a pulp mill by-product. Journal of Applied Polymer Science, 129(5), 2606-2613.

4. Foulet, A., Birot, M., Backov, R., Sonnemann, G., Deleuze, H. (2016). Preparation of hierarchical porous carbonaceous foams from Kraft black liquor. Materials Today Communications, 7, 108-116. 
5. Foulet, A., Birot, M., Sonnemann, G., Deleuze, H. (2015). The potential of Kraft black liquor to produce biobased emulsion-templated porous materials. Reactive and Functional Polymers, 90, 15-20.

6. García, B. B., Liu, D., Sepehri, S., Candelaria, S., Beckham, D. M., Savage, L. W., Cao, G. (2010). Hexamethylenetetramine multiple catalysis as a porosity and pore size modifier in carbon cryogels. Journal of Non-Crystalline Solids. 356(33-34):1620-25.

7. Harkin, J. M., Rowe, J. W. (1971). Bark and its possible uses. U.S. Department of Agriculture, Forest Service and Forest Product Laboratory, 60.

8. Jin, Fan Long, Miao Zhao, Mira Park, Soo Jin Park. (2019). "Recent trends of foaming in polymer processing: A review”. Polymers 11(6):1-24.

9. Ksibi, M., Amor, S. Ben, Cherif, S., Elaloui, E., Houas, A., Elaloui, M. (2003). Photodegradation of lignin from black liquor using a UV/TiO2 system. Journal of Photochemistry and Photobiology A: Chemistry, 154(23), 211-218.

10. Kurańska, M., Pinto, J. A., Salach, K., Barreiro, M. F., Prociak, A. (2020). Synthesis of thermal insulating polyurethane foams from lignin and rapeseed-based polyols: A comparative study. Industrial Crops and Products, 143, 111882.

11. Luo, S., Gao, L., Guo, W. (2020). Effect of incorporation of lignin as bio-polyol on the performance of rigid lightweight wood-polyurethane composite foams. Journal of Wood Science, 66(1), 1-10.

12. Mathias, J. D., Tessier-Doyen, N., Michaud, P. (2011). Development of a chitosan-based biofoam: Application to the processing of a porous ceramic material. International Journal of Molecular Sciences, 12(2), 1175-1186.

13. Merle, J., Birot, M., Deleuze, H., Trinsoutrot, P., Carré, H., Huyette, Q., Charrier-El Bouhtoury, F. (2019). Valorization of Kraft black liquor and tannins via porous material production. Arabian Journal of Chemistry, 12(8), 4731-4739.

14. Özgenç, Ö., Durmaz, S., Kustas, S. (2017). Chemical analysis of tree barks using ATR-FTIR spectroscopy and conventional techniques. BioResources, 12(4), 9143-9151.

15. Pramod, K., Suneesh, C. V., Shanavas, S., Ansari, S. H., Ali, J. (2015). Unveiling the compatibility of eugenol with formulation excipients by systematic drug-excipient compatibility studies. Journal of Analytical Science and Technology 6(1).

16. Ren, W., Tian, G., Jian, S., Gu, Z., Zhou, L., Yan, L., Jin, S., Yina, W., Zhao, Y. (2012). TWEEN coated NaYF4: Yb,Er/NaYF4 core/shell upconversion nanoparticles for bioimaging and drug delivery. The Royal Society of Chemistry Advances, 2, 7037-7041.

17. Risanto, L., Hermiati, E., Sudiyani, Y. (2014). Properties of Lignin from Oil Palm Empty Fruit Bunch and Its Application for Plywood Adhesive. Makara Journal of Technology, 18(2), 67.

18. Xue, B. L., Wen, J. L., Sun, R. C. (2014). Lignin-based rigid polyurethane foam reinforced with pulp fiber: synthesis and characterization. ACS Sustainable Chemistry \& Engineering, 2(6), 1474-1480.

19. Zaied, M., Bellakhal, N. (2009). Electrocoagulation treatment of black liquor from paper industry. Journal of Hazardous Materials, 163(2-3), 995-1000.

20. Zhang, X., Jeremic, D., Kim, Y., Street, J., Shmulsky, R. (2018). Effects of surface functionalization of lignin on synthesis and properties of rigid bio-based polyurethanes foams. Polymers, 10(7), 706. 